\title{
The Antibacterial Activity of Actinomycetes Against the Growth of Streptococcus mutans and Lactobacillus acidophilus
}

\author{
Deby Kania Tri Putri ${ }^{1,}$ Fadel Amirda ${ }^{2}$, Hilman Muzadi ${ }^{2}$, Amy Nindia Carabelly ${ }^{2}$, Isyana Erlita $^{3}$, Rahmiati $^{4}$ \\ ${ }^{1)}$ Departement of Biomedic Faculty of Dentistry Lambung Mangkurat University, Banjarmasin \\ ${ }^{2)}$ Departement of Biology Oral Faculty of Dentistry Lambung Mangkurat University, Banjarmasin \\ ${ }^{3)}$ Departement of Endodontics Faculty of Dentistry Lambung Mangkurat University, Banjarmasin \\ ${ }^{4)}$ Departement of Microbiology Parasitology Faculty of Medical Lambung Mangkurat University, Banjarmasin
}

\begin{abstract}
Antibacterial compounds are generally produced from many herbal ingredients, but antibacterials may be produced from soil microbes, one of which is Actinomycetes. Actinomycetes are a soil bacterium capable of producing secondary metabolites in the form of antibacterial compounds. The antibacterial compound has the potential as an alternative antibacterial agent against oral microbes. One of the oral microbes that have a major role in the occurrence of caries is Streptococcus mutans and Lactobacillus acidophilus. This study aimed to analyze the antibacterial activity of Actinomycetes against the growth of $S$. mutans and $L$. acidophilus Actinomycetes extracts at the concentration of $0.625 \%, 1.25 \%, 2.5 \%, 5 \%, 10 \%$, $20 \%$, and $40 \%$ were respectively exerted as the treatment groups while $0.12 \%$ Chlorhexidine Gluconate $(\mathrm{CHX})$ and aquadest as control. The measurement of antibacterial activity is done by looking at MIC and MBC. One Way ANOVA and Post Hoc Dunnets T3 test MIC and MBC values show $\mathrm{p}=0,000(\mathrm{p}<0.05)$. Actinomycetes extract at the concentration of $0.625 \%$ was able to inhibit the growth of $S$. mutans and L. acidophilus which was determined as the MIC and at the concentration of $40 \%$ as $\mathrm{MBC}$ of S.mutans and the concentration of $10 \%$ as MBC of $L$. acidophilus. There was an antibacterial activity of Actinomycetes to the growth of $S$. mutans and L.acidophilus.
\end{abstract}

\section{Introduction}

Indonesia is one of the countries having the most extensive peatlands compared to other tropical countries, which is around 21 million ha, mainly spread to the is lands of Kalimantan, Sumatra, and Papua. Peatland is an ecosystem included as wetlands. This type of land was formed due to the accumulation of organic material over a long period, compared to the slow rate of decomposing organic matter in the wet or inundated parts of the forest. This process of organic materials, decomposition, or breakdown can occur without the role of microbes [1]. One of the most abundant soil microbes is Actinomycetes [2].

Actinomycetes can produce various secondary metabolites acting as an antibacterial agent [3]. Several studies on Actinomycetes confirmed their ability to produce antibacterial compounds. Adriani [10] isolated Actinomycetes from soil samples taken in Takalar. Two isolates were shown to have antibacterial activity against E. Coli and Staphylococcus aureus. Rante et al (2017) studied the Actinomycetes isolated from the soil rhizosphere. They examined the effect of Actinomycetes extract with a concentration of $5 \%, 10 \%$, and $20 \%$ to Staphylococcus aureus. The result concluded that Actinomycetes extract with a concentration of $20 \%$ had the widest inhibitory zone against Staphylococcus aureus. Staphylococcus aureus is a normal flora inside the mouth cavity [4].

The oral cavity is the perfect habitat for various bacteria. The most common bacteria associated with dental caries are Streptococcus mutans (S. mutans) and Lactobacillus acidophilus (L. acidophilus). S. mutans is lactic acid-producing bacteria and with $L$. acidophilus plays a role in developing advanced carious lesions. These bacteria can metabolize the glucose in the food into organic acids rapidly, thus increasing the acidity inside the oral cavity and speed up the process of caries [5]. Dental caries is a disease of the hard tissue of the teeth commonly found in Indonesia. Indonesian Basic Health Research in 2013 stated that there was a 9.8\% increase in the prevalence of dental caries in Indonesia, from $43.4 \%$ in 2007 to $53.2 \%$ in 2013 , and the experience of caries patient increased by $5.1 \%$, from $67.2 \%$ in 2007 to $72.3 \%$ in 2013. Based on Indonesian Basic Health Research in 2018, dental and mouth problems in Indonesia had a very significant increase from $25.9 \%$ in 2013 to $57.6 \%$ in 2018 [6,7].

The growth inhibition of $S$. mutans and $L$. acidophilus could be performed by giving antibacterial agents. Many have developed various types of antibacterial compounds that originated from natural extracts, included biochemistry. Researches in recent years have also shown the ability of bacterial cells to produce secondary metabolites as antibacterial agents that act as self-defense against unfavorable environmental conditions. Bacteria that can produce antibacterial compounds are generally isolated from food ingredients. In recent years the study of antibacterial compounds from soil bacteria has become a concern [8]. No research has been done to assess the antibacterial activity of Actinomycetes against oral bacteria $S$. mutans and $L$. acidophilus. Based on the description, it is necessary to

Corresponding author: debykania98@gmail.com 
research the antibacterial activity of Actinomycetes against the growth of $S$. mutans and L. acidophilus bacteria.

\section{Materials and Methods}

This study used a true experimental post-test only with control group design method. The treatment groups in this study were Actinomycetes extract with various concentrations: $0.625 \%, 1.25 \%, 2.5 \%, 5 \%, 10 \%, 20 \%$, $40 \%$, positive control (chlorhexidine gluconate $0.12 \%$ ) and negative controls (aquadest). Based on the results of the Federer formula, the minimum number of repetitions obtained per group is 3 times.

\subsection{Sterilization}

The initial procedure of the study was to sterilize the tools that had been washed clean and coated with aluminum foil using an autoclave for 15 minutes at $121^{\circ} \mathrm{C}$.

\subsection{Rejuvenation of Actinomycetes culture}

Actinomycetes InaCC A156 culture obtained from the INACC laboratory of the Indonesian Institute of Sciences Bogor was rejuvenated by taking a colony using sterile ose and then transferred to YSA media and incubated for $14 \times 24$ hours at $37^{\circ} \mathrm{C}$.

\subsection{Extraction of Actinomycetes}

After 14 days of incubation, the agar plate overgrown with microbes was mashed using a blender. The media was then extracted using a maceration method with ethyl acetate solvent in a 1: 5 ratio. Extraction was carried out for 8 hours on a maceration vessel and stirring every 2 hours. The macerate was then filtered using filter paper, obtaining the liquid extract. The extract subsequently was evaporated using a rotary evaporator to obtain the dry extract.

\subsection{Preparation of Bacterial Testing}

In the preparation of bacterial testing, Streptococcus mutans and Lactobacillus acidophilus colonies from pure isolates were planted on Nutrient Agar (NA) media and incubated for $1 \times 24$ hours at $37^{\circ} \mathrm{C}$, then the bacteria were inoculated into $0.5 \mathrm{ml}$ of liquid $\mathrm{BHI}$, incubated for another $1 \times 24$ hour at $37^{\circ} \mathrm{C}$. The suspension solution was then added with sterile distilled water until the turbidity was proportional to the McFarland standard of 0.5 or the bacteria equivalent to the amount of $1.5 \times 10^{8} \mathrm{CFU}$.

\subsection{Minimum Inhibitory Concentration (MIC)}

The extracts from the Actinomycetes culture were made into 7 different concentrations: $0.625 \%, 1.25 \%, 2.5 \%$, $5 \%, 10 \%, 20 \%$ and $40 \%$. Hereafter, the testing bacteria standardized with McFarland $0.5\left(1,5 \times 10^{8} \mathrm{CFU} / \mathrm{ml}\right)$ were diluted using a test tube filled with liquid media and several testing bacteria. The test tube was measured for its turbidity before and after incubation for 24 hours using a UV-Vis spectrophotometer. The difference in the turbidity value was measured to determine the minimum inhibitory content (MIC).

\subsection{Minimum Bactericidal Concentration (MBC)}

Actinomycetes extracts and test bacteria were taken from the test tubes. The samples would be inoculated and spread in agar Nutrient (NA) media and undergo incubation for 24 hours at $37^{\circ} \mathrm{C}$. Finally, the number of Streptococcus mutans and Lactobacillus acidophilus was observed using the Colony counter to get the minimum bactericidal concentration.

\section{Result and Discussion}

\subsection{Results}

In this study, the results of antibacterial activity tests were obtained by measuring the difference between the absorbance values in anaerobic conditions. Each sample from each treatment group was calculated using UV-Vis Spectrophotometry. The wavelength value used before and after incubation, was $420 \mathrm{~nm}$, are provided in Table 1.

Tabel 1. The minimum inhibitory concentration (MIC) test of

\begin{tabular}{|c|c|c|c|c|}
\hline Sample & 0 Hour & 24 Hour & Deviation & Note \\
\hline 1 & 0.38 & 0.33 & -0.05 & Decreased \\
\hline 2 & 0.57 & 0.47 & -0.10 & Decreased \\
\hline 3 & 1.23 & 0.93 & -0.30 & Decreased \\
\hline 4 & 1.28 & 1.46 & 0.18 & Increased \\
\hline 5 & 1.45 & 1.59 & 0.13 & Increased \\
\hline 6 & 2.38 & 2.49 & 0.11 & Increased \\
\hline 7 & 2.52 & 2.73 & 0.20 & Increased \\
\hline 8 & 2.11 & 1.90 & -0.20 & Decreased \\
\hline 9 & 0.35 & 1.23 & 0.87 & Increased \\
\hline
\end{tabular}

Note : 1-7 : Actinomycetes $0.625 \% ; 1.25 \% ; 2.5 \% ; 5 \% ; 10 \%$; $20 \% ; 40 \% ; 8=$ Chlorhexidine gluconate $0.2 \% ; 9=$ Aquadest.

Tabel 2. The minimum inhibitory concentration (MIC) test of Actinomycetes on Lactobacillus acidophilus growth.

\begin{tabular}{ccccc}
\hline Sample & 0 Hour & 24 Hour & Deviation & Note \\
\hline 1 & 0.52 & 0.47 & -0.04 & Decreased \\
2 & 0.75 & 0.64 & -0.10 & Decreased \\
3 & 1.87 & 0.85 & -1.02 & Decreased \\
4 & 2.02 & 2.25 & 0.23 & Increased \\
5 & 2.23 & 2.34 & 0.10 & Increased \\
6 & 2.44 & 2.55 & 0.10 & Increased \\
7 & 2.56 & 2.69 & 0.13 & Increased \\
8 & 1.87 & 1.12 & -0.75 & Decreased \\
9 & 0.31 & 0.87 & 0.56 & Increased \\
\hline Note: $1-7:$ Actinomycetes $0.625 \% ; 1.25 \% ; 2.5 \% ; 5 \% ; 10 \% ;$ \\
$20 \% ; 40 \% ; 8=$ Chlorhexidine gluconate $0.2 \% ; 9=$ Aquadest.
\end{tabular}

Tables 1 and 2 showed the Actinomycetes inhibitory properties of the testing bacteria measured using UV-Vis spectrophotometry by calculating the value difference. 
Actinomycetes extract with a concentration of $0.625 \%$ was found to be ably inhibiting the growth of $S$. mutans and L. acidophilus, marked by the decrease in the absorbance value. In this study, it was found that Actinomycetes extract concentration of $2.5 \%$ had the most effective inhibition compared to other treatment groups including positive control of $0.12 \%$ by chlorhexidine gluconate. The minimum bactericidal concentration was measured next using a colony counter. The result was provided in Table 3.

Tabel 3. The minimum bactericidal concentration (MBC) test on S. mutans after 24-hour incubation.

\begin{tabular}{ccc}
\hline Sample & Replication & Mean \pm SD \\
\hline 1 & 3 & $1216 \pm 94.5$ \\
2 & 3 & $861 \pm 20.1$ \\
3 & 3 & $453 \pm 21.0$ \\
4 & 3 & $216 \pm 10.6$ \\
5 & 3 & $44 \pm 4.0$ \\
6 & 3 & $14 \pm 3.0$ \\
7 & 3 & $0 \pm 0.0$ \\
8 & 3 & $3 \pm 0.6$ \\
9 & 3 & $2112 \pm 79.5$ \\
\hline
\end{tabular}

Note : $1-7$ : Actinomycetes $0.625 \% ; 1.25 \% ; 2.5 \% ; 5 \% ; 10 \%$; $20 \% ; 40 \% ; 8=$ Chlorhexidine gluconate $0.2 \% ; 9=$ Aquadest.

Tabel 4. The minimum bactericidal concentration (MBC) test on L. acidophilus after 24-hour incubation.

\begin{tabular}{ccc}
\hline Sample & Replication & Mean \pm SD \\
\hline 1 & 3 & $232 \pm 22.34$ \\
2 & 3 & $165 \pm 12.12$ \\
3 & 3 & $48.67 \pm 4.94$ \\
4 & 3 & $5 \pm 1$ \\
5 & 3 & $0 \pm 0$ \\
6 & 3 & $0 \pm 0$ \\
7 & 3 & $0 \pm 0$ \\
8 & 3 & $3 \pm 1$ \\
9 & 3 & $472 \pm 24$ \\
\hline
\end{tabular}

Note: $1-7$ : Actinomycetes $0.625 \% ; 1.25 \% ; 2.5 \% ; 5 \% ; 10 \%$; $20 \% ; 40 \% ; 8=$ Chlorhexidine gluconate $0.2 \% ; 9=$ Aquadest.

Tables 3 and 4 provided a result that no S. mutans colony growth was found in Actinomycetes concentrations of $40 \%$ in the Petri dishes. Hence, Actinomycetes extract $40 \%$ was the concentration that acts as bactericidal for $S$. mutans bacteria. On the other hand, in L. acidophilus colonies, Actinomycetes at a concentration as small as $10 \%$ could inhibit the growth of bacterial colonies in Petri dishes completely, thus, a concentration of $10 \%$ is the minimum bactericidal concentration for L. acidophilus bacteria.

Based on the Shapiro Wilk normality test results, the data were normally distributed ( $p$-value $>0.05$ ). The homogeneity test using the Levene test showed that the data was non-homogeneous. Subsequent analysis using parametric tests One Way ANOVA results on $\mathrm{p}$-value = $0,000(\mathrm{p}<0.05)$ meaning there were significant differences. Data analysis was carried on using the Post Hoc Dunnett T3 test. The results provided significant differences $(p<0.05)$ in several groups, while no significant difference in the remaining groups $(p>0.05)$.

\subsection{Discussion}

The result of this Antibacterial Activity of Actinomycetes on The Growth of Streptococcus mutans and Lactobacillus acidophilus study showed that Actinomycetes extracts with concentrations of $0.625 \%$, $1.25 \%, 2.5 \%, 5 \%, 10 \%, 20 \%$, and $40 \%$ could inhibit growth (MIC) of Streptococcus mutans and Lactobacillus acidophilus, starting from a concentration of $0.625 \%$. The bactericidal, however, had a difference in the concentration needed between Streptococcus mutans, (MBC) $40 \%$ and Lactobacillus acidophilus (MBC) 10\%. Actinomycetes extract with concentrations of $0.625 \%$, $1.25 \%$, and $2.5 \%$ measured with Spectrophotometer had decreased absorbance values, in contrast to increased absorbance values found in concentrations of $5 \%, 10 \%$, $20 \%$ and $40 \%$. This increase did not fully indicate the growth of bacterial colonies in the media and could be influenced by the color density of the extract of the test material.

In this study, an increase in pigment was found starting white the turned brownish-yellow. According to Wulandari [9], Actinomycetes were able to change its color based on the composition of the media used. This statement was also supported by Adriani [10] findings that the white-colored Actinomycetes colonies could turn into black. The reasonable explanation was that the change was due to secondary metabolites of secreted compounds containing pigments. The secreted color pigment would vary according to the type of the Actinomycetes. Thus the color changes could affect the absorption of light in turbidity measurement by using the UV-Vis Spectrophotometry method, leading to the smaller concentrations Actinomycetes having better values due to more optimal light absorption and lack of secreted pigment [10].

This study also observed that Actinomycetes extract with a concentration of $0.625 \%$ was found to be the Minimum Inhibitory Concentration (MIC) because of its ability to inhibit the growth of testing bacteria. The presence of antibacterial activity in this study was indicated by the difference in absorbance values which indicates a decrease in the growth of testing bacteria. Actinomycetes were able to produce extracellular enzymes and antibiotic compounds [11]. Extracellular enzymes could degrade complex compounds into simpler compounds to be used in Actinomycetes growth, whereas antibiotic compounds could inhibit the growth of other microbes by interfering with the process of cell wall synthesis and protein synthesis of other microbes [12].

The results of this study also indicated that Actinomycetes extract with a concentration of $2.5 \%$ was the best in terms of inhibiting the growth of $S$. mutans and L. acidophilus bacteria due to the decrease in absorbance value of 0,300 for $S$. mutans and the decrease in absorbance value of 1,02 for L. acidophilus. Actinomycetes extract was effective in inhibiting the growth of testing bacteria by targeting the peptidoglycan of the cell wall. Peptidoglycan is an important layer of bacteria to survive in hypotonic conditions [13]. 
Damage to this layer could disrupt the stiffness of cells, leading to cell death. The difference between grampositive and gram-negative bacteria is in the location and content of the peptidoglycan layer. The gram-positive bacterial cell wall consists of $90 \%$ peptidoglycan and is located on the outside, while gram-negative bacteria only have $10 \%$ located between lipopolysaccharide and phospholipids. Therefore, common antibacterial compounds have to pass through a narrow channel before reaching peptidoglycan [13]. Streptococcus mutans and Lactobacillus acidophilus are both gram-positive bacteria, thus it is reasonable that Actinomycetes could inhibit the growth of both bacteria. Chlorhexidine gluconate $0.12 \%$ as a positive control was only able to disrupt bacterial cell transport, creating small holes in the cell membrane and leakage of $S$. mutans and L.Acidophilus cells, causing slow cell death [14].

The antibacterial activity of Actinomycetes was yielded by secondary metabolites. Secondary metabolites are molecules and metabolic products produced by microorganisms through secondary metabolic processes where the metabolic product is not a primary requirement for microorganisms to grow and develop. Although not always needed for growth, secondary metabolites could act as an emergency nutrient for survival [15]. There are several functions of secondary metabolites for secondary metabolites-producing bacteria, for example in maintaining life from other bacteria, fungi, insects, animals, and other species [14]. The secondary metabolism is only active at certain times, mainly during unfavorable periods for bacterial growth due to lack of nutrition or microbial invasion [17].

Bactericidal activity in this study was observed from the number of growing bacterial colonies in the media incubated for 24 hours using the Colony counter. The bactericidal activity could be indicated in the absence of bacterial colony growth completely or equal to 0 $\mathrm{CFU} / \mu \mathrm{l}$. MBC test results showed that Actinomycetes extract was effective for killing $S$. mutans (concentration of $40 \%$ ) and Lactobacillus acidophilus (concentration of $10 \%$ ). Accumulated bacterial colonies would generally form a biofilm. The biofilms are a defense mechanism of bacterial colonies against external factors. Biofilms were found to have an extracellular matrix called Extracellular Polymeric Substance (EPS) to support its function [17].

Antibacterial agents are unable to penetrate the biofilm layer due to its extracellular matrix which inhibits the antibacterial diffusion and binding [17]. Several types of secondary metabolite compounds are known to have antibiofilm properties as they can inhibit the formation of intercellular adhesion genes icaA and icaD [18]. The icaA and icaD genes will synthesize Polysaccharide Intercellular Adhesion (PIA) which plays an important role in biofilm formation, namely cell aggregation and the formation of Extracellular Polymeric Substance (EPS), which will facilitate antibacterial interference easily diffusing into the biofilms layers [19].

Actinomycetes extract had a potency to be used as a topical antibacterial agent in the oral cavity either in the form of gels, pastes or mouthwash with the other additional ingredients due to its secondary metabolite extracts particularly at a concentration of $2.5 \%$ having a high inhibitory effect/activity exceeding the positive control itself (Chlorhexidine gluconate $0.12 \%$ ). It can be concluded that there was an antibacterial activity of Actinomycetes against the growth of $S$. mutans and $L$. acidophilus.

\section{References}

1. D. Mahdiyah. Isolasi Bakteri dari Tanah Gambut Penghasil Enzim Protease. Jurnal Pharmascience. 2 (2): 71-79, (2015)

2. N. Istiana, R.M. Roza, A. Martina. Uji Aktivitas Aktinomisetes Lahan Gambut Rimbo Panjang Kampar Riau sebagai Agen Biokontrol Terhadap Ganoderma boninense (Pat.). JOM FMIPA. 2 (2): 1$8,(2015)$

3. N. Antriana. Isolasi dan Penapisan Aktinomiset Penghasil Senyawa Antibakteri dari Lingkungan. Riset Informasi Kesehatan. 5 (2): 115-119, (2015)

4. E. Jawetz, J.L. Melnick, G.F. Brook et al., Mikrobiologi Kedokteran. 25th edition. New York: McGrawhill Medical, p. 214, (2010)

5. T.M. Karpinski, A.K. Szkaradkiewicz. Mikrobiology of Dental Caries. Journal of Biology and Earth Science. 3 (1): M21-M24, (2013)

6. Balitbang Kemenkes RI. Riset Kesehatan Dasar. Jakarta: Balitbang Kemenkes RI; p. 110-119, (2013)

7. Balitbang Kemenkes RI. Hasil Utama Riset Kesehatan Dasar 2018. Jakarta: Kemenkes RI; p. 9396, (2018)

8. Erlindawati, P. Ardiningsih, A. Jayuska. Identifikasi dan Uji Aktivitas Antibakteri dari Tiga Isolat Bakteri Tanah Gambut Kalimantan Barat. JKK. 4 (1): 12-16, (2015)

9. S. Wulandari, N. Sulistyani. Pengaruh Media Terhadap Pertumbuhan Isolat Actinomycetes Kode AL35 serta Optimasi Produksi Metabolit Antibakteri Berdasarkan Waktu Fermentasi dan pH. Media Farmasi. 13(2): 186-198, (2016)

10. Adriani, Y.F Tulak. Isolasi dan Karakterisasi Actinomycetes Sebagai Penghasil Antibiotik Dari Sampel Tanah Pada Pertenakan Sapi di Kecamatan Galesong Kabupaten Takalar. Biogenesis Jurnal Ilmiah Biologi. 1 (2): 97-100, (2013)

11. A.M. Kumalasari, N. Fathurahman, Muhamad Nur R. Potensi Actinomycetes sebagai Sumber Senyawa Bioaktif Antibiotik dari Kawasan Karst Bantimurung, Sulawesi Selatan. Pelita. 7(1): 59-72, (2012)

12. S. Tasnim, K. Retno, Ni Putu AA. Efektivitas Daya Hambat Bakteri Streptomyces sp Terhadap Erwinia $s p$ Penyebab Penyakit Busuk Rebah Pada Tanaman Lidah Buaya (Aloe barbadensis Mill). Jurnal Simbiosis. 1(1): 21-27, (2013)

13. N. Sardiani, A. Litaay, et al. Potensi Tunikata Rhopalaea sp. sebagai Sumber Inokulum Bakteri Endosimbion Penghasil Antibakteri; 1. Karakterisasi 
Isolat. Jurnal Alam dan Lingkungan; 6 (11): 1-10, (2015)

14. D. Permatasari, L.Y. Budiarti, M.L. Apriasari. Efektivitas Antifungi Ekstrak Metanol Batang Pisang Mauli (Musa acuminata) dan Chlorhexidine Gluconate $0,2 \%$ Terhadap Candida albicans. Dentino Jurnal Kedokteran Gigi. 1 (1): 10-14, (2016)

15. F. Rhamadhani, A.M. Ramadhan, L. Rijai. Aktivitas Antibakteri Daun Jahe Balikpapan (Etlingera balikpapanensis). Prosiding Kefarmasian Samarinda. 4 (1): 118-124, (2016)

16. B. Kusbiantoro, Y. Purwaningrum. Pemanfaatan Kandungan Metabolit Sekunder Tanaman Kunyit Dalam Mendukung Peningkatan Pendapatan Masyarakat. Jurnal Kultivasi. 17 (1): 544-549, (2018)
17. P.A. Suryanditha, Y.D. Rasita, K. Debora, K. Kuntaman. Icaa/D Genes And Biofilm Formation Of Methicillin-Resistant Staphylococcus aureus In Dr. Soetomo Hospital, Surabaya. 54 (4): 263-268, (2018)

18. J.H. Lee, J.H. Park, H.S. Cho, S.W. Joo, M.H. Cho, J. Lee. Anti-biofilm activities of quercetin and tannic acid against Staphylococcus aureus. Biofouling: The Journal of Bioadhesion and Biofilm Research, 29 (5) : 491-499, (2013)

19. H. Rohde, S. Frankenberger, U. Zahringer, D. Mack. Structure, function and contribution of polysaccharide intercellular adhesin (PIA) to Staphylococcus epidermidis biofilm formation and pathogenesis of biomaterial-associated infections. European Journal of Cell Biology 89 (1): 103-111, (2010) 